\title{
An Analysis of Domain Mood and Modality of Interpersonal Meaning in Susilo Bambang Yudhoyono (SBY)'s Speech
}

\author{
${ }^{1}$ Mustika Amalia, ${ }^{2}$ Dedy Subandowo, ${ }^{3}$ Eva Faliyanti, ${ }^{4}$ Fenny Thresia \\ Universitas Muhammadiyah Metro \\ ${ }^{1}$ mustika0542@gmail.com, ${ }^{2}$ dedy.subandowo@ummetro.ac.id, \\ 3evafaliyanti1980@gmail.com, ${ }^{4}$ fenny.thresia@yahoo.com
}

\begin{abstract}
This research examines the interpersonal meaning in Susilo Bambang Yudhoyono (SBY)'s speech. This is based on the details of speech or writing to define an investigation. The object of this research is the used moods and modality types in interpersonal meaning of SBY's speech under the title "Toward Harmony among Civilizations" by Dr.Susilo Bambang Yudhoyono. The aims of this research are (1) to observe the mood and modality types used in SBY's speech, (2) to observe the dominant mood and modality types in SBY's speech, (3) to describe the interpersonal meaning in case of mood and modality types in SBY's speech. The main sources of data in this study are taken from the SBY's speech at the John F. Kennedy School of Government Harvard University summit on September $29^{\text {th }}, 2009$, in Boston, USA. The data then are classified and collected in tabulation. This paper is based on the discourse analysis and systemic functional linguistics approach by Halliday. The writer analyses the speeh by SBY mainly from the interpersonal meaning which focuses on the mood and modality types. The results of this research are (1) there are two mood types in interpersonal meaning of SBY's speech namely indicative and imperative type, (2) the dominant mood in SBY's speech is the indicative type which is declarative with the total number of 97 clauses or around $95 \%$, while the dominant used modality is "can". In addition, the overall dominant modality type exists in median degree modality with the total percentage $40,6 \%$, and (3) the researcher discovers the different mood and modality that might affect the value of the speech to the audience.
\end{abstract}

Keywords: discourse analysis, interpersonal meaning, speech of SBY, systemic functional linguistic

How to Cite: Amalia, M., Subandowo, D., Faliyanti, E., Thresia, F. (2018). An Analysis of Domain Mood and Modality of Interpersonal Meaning in Susilo Bambang Yudhoyono (SBY)'s Speech. English Language Teaching Educational Journal, 1(1), 22-28.

\section{INTRODUCTION}

Language is a natural part of the process of living (Halloran, 2008). Language is used for communication and that is called discourse (Gee, 2014) and (Wetherell, 2001). The researcher conducts a linguistic research on the interpersonal meaning which analyzed mood and modality types in the speech of Susilo Bambang Yudhoyono (SBY). The speech was delivered on September $29^{\text {th }}, 2009$ at John F. Kennedy School of Government Harvard University with the topic "Towards Harmony among Civilizations".

This research focuses on mood and modality in the interpersonal relationship that can be seen through the interpersonal meaning realized on the 
speech. Mood types in English depend on the position of the subject like the doer, and the finite which is used in the clause. According to Gart \& Wignellin (Halliday M. \& Matthiessen, 2004) there are two main categories in mood types :indicative and imperative moods (Haratyan, 2011) and (Matthiessen\& Halliday, 2009).

People use interpersonal meaning in communicating to his/her motion, feeling, etc (Sadighi,2008) and (Feng\& Liu,2010). These express the speaker or writer's judgments on or attitude to the content of the message. The elements of interpersonal meanings are mood and residue. Mood element carries the interpersonal functions of the clause and consists of subject and finite (Halliday \&Matthiessen, 2014).

The research relating to this topic has been done by Wang (2017) that tested on the effect of using mood and modality interactivity under the context of smart phones news reading. This study showed that mood, modality interactivity, or news story length had no direct impact on user engagement. However, there was a combinatory effect of mood, length, and topic on dimensions of user engagement. On the other hand, Ko (2018) researhced on systemic functional grammar to Korean Texts. This study mentioned that there are three metafunctions of SFG: experiential, textual and interpersonal. The study subsequently provides a sample text analysis of email and personal diary writing of two Korean ESL children, thereby demonstrating the feasibility of applying SFG to Korean texts. Furthermore, Tokunaga (2017) examined the mood and modality on transactional monologues like procedural texts. This study evaluated that interpersonal meanings are made not just in highly interactive dialogic modes of discourse such as conversations, where maintaining and negotiating social relationships is key, but transactional monologues as well.

Based on the phenomenon above, the research tries to conduct analysis on mood and modality in interpersonal meaning of the SBY's speech. The researcher wonders how mood and modality realize in SBY's speech and how the interpersonal meaning creates the speaker's action to the listeners. It is important to find out the goal of SBY as the speaker conveying his speech.

\section{RESEARH METHOD}

This research is qualitative research which concerned with developing explanations of social phenomena (Hancock, Ockleford, \&Windridge, 2009), (Sandelowski, 2000) and (Cochran, 2002). This study is categorized into documentary research regarding with the data that is taken from the document or written text; speech. Based on Grix (2001) in (Mogalakwe, 2006) states that documents are produced by individuals and groups in the course of their everyday practices and are geared exclusively for their own immediate practical (Bowen, 2009) and (Voice, 2012). The speech of SBY was downloaded from https://ombenk.wordpress.com/2010/06/29/idato-presiden-sby-yang-terpilihsebagaipidato- terbaik-abad-21/.In processing the data, the first step was giving a code and mark to the found mood and modality types in the script of SBY's 
speech. The second step was observing the mood and modality types realized in the script of SBY's speech. The further step was observing the dominant mood and modality types in script of SBY's speech. Then Describing the interpersonal meaning in case of mood and modality types in SBY's speech based on Systemic Functional Linguistics theory in discourse analysis.

\section{RESULTS}

The finding of the research showed that there are two kinds of mood types, namely indicative and imperative. Indicative type has two types; those are declarative and interrogative. In terms of modality, SBY applies 10 modalities which kind of low, middle and high category in his speech.

The dominant mood used in the speech is declarative mood and followed by the interrogative and imperative. There are 97 clauses identified as declarative mood or around 95\% in SBY's speech, and it is followed by 4 clauses or over $3,9 \%$ as interrogative mood, and 1 clause or about $0,9 \%$ as imperative mood.

Table 1. The dominant mood type

\begin{tabular}{|c|c|c|c|c|}
\hline Mood Types & $\begin{array}{l}\text { Speech } \\
\text { Function }\end{array}$ & $\begin{array}{l}\text { Mood } \\
\text { Element }\end{array}$ & Appearance & Percentage \\
\hline Declarative & Statement & $\begin{array}{l}\text { Subject } \\
+ \text { Finite }\end{array}$ & 97 & $95 \%$ \\
\hline Interrogative & Question & $\begin{array}{l}\text { Finite } \\
+ \text { Subject } \\
\text { WH/ Finite } \\
+ \text { Subje ct }\end{array}$ & 4 & $3,9 \%$ \\
\hline Imperative & Command & Finite & 1 & $0,9 \%$ \\
\hline \multicolumn{3}{|c|}{ Total Clause } & 102 & $\begin{array}{c}100 \\
\%\end{array}$ \\
\hline
\end{tabular}

The table is about the dominant modality which showed the middle degree with 41 modal or around 40,6\%, and followed low degree with 40 modal or around $39,6 \%$, then the high degree with 20 orover $19,8 \%$. The researcher discovers the different mood and modality can affect the value of the speech to the audience. As declarative type is the dominant mood type in SBY's speech, this means that SBY gave information to the audience. Modality expresses the speaker's judgment of how likely or unlikely he is toward the thing that he says. The dominant modality in SBY's speech is can which is used to describe the ability of the subject to do or to make something. Apart from likely or unlikely "can" could be used as "permission". Yet, overall, the dominant modality type does exist in median degree. This degree is served by modal will, should, would, and shouldn't. It shows that the speaker is declaring his speech courteously, or in the median politeness. 
Table 2. The dominant modality type

\begin{tabular}{|c|c|c|c|}
\hline Degree & Modality & Appearance & Percent age \\
\hline \multirow[t]{4}{*}{ Low } & Can & 32 & \\
\hline & Could & 3 & \\
\hline & May & 3 & \\
\hline & Cannot & 2 & \\
\hline \multicolumn{2}{|c|}{ Result } & 40 & $39,6 \%$ \\
\hline Middle/ & Will & 17 & \\
\hline \multirow[t]{3}{*}{ Medium } & Would & 14 & \\
\hline & Should & 7 & \\
\hline & Should n't & 3 & \\
\hline \multicolumn{2}{|c|}{ Result } & 41 & $40,6 \%$ \\
\hline \multirow[t]{3}{*}{ High } & Must & 19 & \\
\hline & Have to & 1 & \\
\hline & & 20 & $19,8 \%$ \\
\hline \multicolumn{2}{|c|}{$\begin{array}{r}\text { Total (Low }+ \text { Middle } \\
+ \text { High })\end{array}$} & $\begin{array}{c}40+41+20= \\
101\end{array}$ & $100 \%$ \\
\hline
\end{tabular}

\section{FINDING AND DISCUSSION}

From the result of the analysis, the researcher received the data of mood types. The data consist of 97 clauses or all over $95 \%$ of declarative clause, 4 clauses or about 3,9\% of interrogative clause, and 1 clause or around $0,9 \%$ of imperative clause. The dominant mood used in the speech is declarative type, and it is followed by the interrogative and the imperative one. In declarative mood, SBY formed the nine steps to build the harmony of civilization. Then interrogative mood, SBY preferred to use WH-elements in representing his questions and demanding the reasons to make the work globally between Indonesia and America. The last imperative mood in SBY's speech is used to demand the information from the Indonesia to America.

The result of modality is about 101 modals in total. The speaker tends to use modal can, but the modality types consist of 40 modals or around $39.6 \%$ of low degree, 41 modals or about $40,6 \%$ of medium/middle degree, and 20 modals or around $19,8 \%$ of high degree.

The writer found the dominant mood type is declarative clause. Meanwhile, the speaker tends to use modal can in his speech which included low degree. However, from the percentage of modality, the dominant shows middle degree.

The mood is the valuable thing in realizing interpersonal meaning for it is the main point in bearing the speaker's attitudes and judgments. Since mood is built by subject and finite, and the chosen finite is modality, the researcher 
interprets the clause which consists modal in it. SBY tends to use modal "can" that aims to convince and persuade the audience to deal with the idea of the speaker,while the researcher discovers that the dominant modality type is in middle degree. It means that the speaker is conveying the speech in way of median politeness.

\section{CONCLUSION}

The researcher found that there are two mood types in interpersonal meaning of SBY's speech namely indicative and imperative type, Indicative type consists of declarative and interrogative. Based on the analysis of mood type, the researcher reveived the data 97 clauses of declarative with the percentage around 96\%, 4 clauses of interrogative with the total percentage $3,9 \%$, and 1 clause of imperative with $0,9 \%$. The modality in that speech is 10 modals, there are 32 of "can", 3 of "could", 3 of "may", 2 of "cannot", 17 of "will",14 of "would", 7 of "should", 2 of "shouldn't", 19 of "must", 1 of "have to". The details of those types are the first low degree (can, could, may, cannot) with the total percentage of $39,60 \%$, then middle degree (will, would, should, shouldn't) with the $40,60 \%$, and the last is high degree (must, have to) with $19,8 \%$.

The dominant mood in SBY's speech is the indicative type that is declarative with 97 clauses or around $95 \%$, while the dominant modality is can. Yet, overall, the dominant modality type exists in median degree modality with the percentage $40, \%$.

This research uses SBY's speech as an example to show how interpersonal meaning is realized in a speech, especially in a political speech. From the explanation in the previous chapter, the researcher discovers that the different mood and modality can affect the value of the speech to the audience. As declarative type is the dominant mood type in SBY's speech, this means that SBY gave information to audience. Modality expresses the speaker's judgment of how likely or unlikely he is the thing that he says. The dominant modality in SBY's speech is can which is used to describe the ability of the subject to do or to make something. Apart from likely or unlikely "can" could be used "permission". Yet, overall, the dominant modality type exists in median degree. This degree is served by modal will, should, would, and shouldn't. It shows that the speaker is declaring his speech courteously, or in the median politeness. The realized modality type in median degree is $40,6 \%$ of all data.

\section{REFERENCES}

Bowen, G. A. (2009). Document Analysis as a Qualitative Research Method. Qualitative Research Journal.

Cochran, M. Q. (2002). qualitative-Research-Methodology.pdf. Dipetik April Friday,2017, darihttp://d1pbog36rugm0t.cloudfront.net: http://d1pbog36rugm0t.cloudfront.net/-/media/science/research-andteaching/teaching/qualitative-research-methodology.pdf 
Feng, H.,\& Liu,Y.(2010).Analysis of Interpersonal Meaning in Public Speeches- A Case Study of Obama's Speech. Journal of Language Teaching and Research.

Gee, J. P. (2014).An Introduction to Discourse Analysis:Theory and Method. Newyork: Routledge.

Halliday, M., \& Matthiessen. (2004). An Introduction To Functional Grammar 3d.ed. London: Arnold.

Halliday, M., \&Matthiessen, C. (2014). Hallida's Introduction to Functional Grammar. USA: Routledge.

Halloran, K. O. (2008). Visual Communication.

Hancock,B.,Ockleford, E.,\&Windridge,K. (2009).An Introduction to Qualitative Research. National Institute For Health Research.

Haratyan,F.(2011). Halliday's SFL and Social Meaning. Internatioanal Conferenceon Humanities, Historical and Social Sciences.

Ko, B. A. (2018). Applying Systemic Functional Grammar to Korean Texts: Transitivity, Mood/Modality, and Theme. 언어와 언어학, 79, 45-76.

Matthiessen, C., \& Halliday, M. (2009). Systemic Functional Grammar: A First Step Into TheTheory.

Mogalakwe,M. (2006). The Use Of Documentary Research Methods in Sosial Research. African Sociological Review.

Pidato Presiden SBY Terpilih Sebagai Pidato Terbaik. Dipetik August Sunday, 2016, dari https://ombenk.wordpress.comError! Hyperlink reference not valid.2010/06/29/pidato-presiden-sby-yang- terpilih-sebagai-pidato-terbaikabad-21/

Sadighi, M.B. (2008). Chomsky'sUniversal Grammarand Halliday's Systemic Functional Linguistics:An Appraisaland aCompromise. JournalofPan-Pacific Association ofApplied Linguistics, 12(1),11-28.

Sandelowski, M. (2000). Focuson Research Methods: What Happened to Qualitative Description? Research in Nursing \& Health.

Tokunaga, A. (2017). Comparing Patterns of Mood and Modality in a Recipe and a Demonstration. 
Wetherell,M., Taylor,S., \& Lates, S. (2001). A discourse As Data: A Guide Of Analysis. London: Sage Publication Ltd.

Wang, R. (2017). Reading News on Smartphones: How Do Mood, Modality Interactivity, And News Story Length. 